\title{
The Asymmetric Link between Public Debt and Private Investment in Malaysia
}

\author{
Siew Yee $\mathrm{Lau}^{\mathrm{a}}$ \\ University of Nottingham Malaysia \\ Ai Lian $\operatorname{Tan}^{\mathrm{b}}$ \\ Universiti Tunku Abdul Rahman \\ Chung Yee Liew ${ }^{c}$ \\ Universiti Tunku Abdul Rahman
}

\begin{abstract}
This paper intends to examine the existence of asymmetric effect of public debt on private investment in Malaysia. As Malaysia's public debt has been rising in recent years the question has been raised on whether the persistently high debt level can negatively affect private investment or otherwise. This study, which uses non-linear autoregressive distributed lags (NARDL) estimation with data from 1980 to 2016, shows some evidence of asymmetrical effect in private investment-public debt nexus in both the long- and short-run. There are evidences of long-run asymmetry between private investment and total public debt, external debt, and federal government debt. In the short run, asymmetric relationship exists between private investment and domestic debt, external debt, and federal government debt. The findings also conclude that, in both long-run and short-run, higher public debt crowds out private investment, which is in line with the crowding-out effect hypothesis. Hence, policy-makers are advised to maintain public debt at a healthy level to ensure private investment is not being crowded-out.
\end{abstract}

Keywords: Public debt, private investment, asymmetric relationship, NARDL JEL classification: E22, H63

\section{Introduction}

High levels of public debt have been a concern of Southeast Asian countries, including Malaysia whose level of debt to gross domestic product (GDP) is higher than $50 \%$ since 2011, which may spark a risk of debt crisis in the country. Malaysia's public debt peaked at 54.5\% of GDP in 2014 and decreased slightly to 51.1\% in 2017 (Edge Weekly, 2018). Even though the government has imposed a debt limit of 55\% of GDP, there are

a School of Economics, University of Nottingham Malaysia, Jalan Broga, 43500 Semenyih, Selangor, Malaysia. E-mail: siewyee.lau@nottingham.edu.my (Corresponding author)

b Faculty of Business and Finance, Universiti Tunku Abdul Rahman, UTAR Kampar Campus, Jalan Universiti Bandar Barat, 31900 Kampar, Perak, Malaysia. Email: tanal@utar.edu.my

c Faculty of Business and Finance, Universiti Tunku Abdul Rahman, UTAR Kampar Campus, Jalan Universiti Bandar Barat, 31900 Kampar, Perak, Malaysia. Email: cyliew@utar.edu.my

Article Info: Received 15 March 2019; Revised 16 July 2019; Accepted 27 September 2019

https://doi.org/10.22452/MJES.vol56no2.8 
two problems on the imposition of this debt limit. First, the level of the limit is selfimposed, in which the government can easily adjust or abolish the limit for political interest. Second, the calculation of the limit varies according to the definition of public debt. For example, some governments, including Malaysia, define public debt as equal to central government debt while others claim that it includes central government debt as well as state governments' and public sector agencies' debts. However, the external debt to gross national income for Malaysia stood at $69.6 \%$ in 2016, the next highest debt ratio after Laos (93.1\%) in the region, as compared to an average of $26 \%$ in developing countries. Its low ratio of foreign reserves to short-term external debt also projects a relatively high risk of distress: in 2016, Malaysia's foreign currency reserves were only 1.1 times the amount of the short-term debt (Haswidi, 2018). Surging public debt raises important questions regarding whether a country's debt profile affects its avenue of growth.

One of the questions is whether rising public debt affects private investment, a mechanism that explains the relationship between public debt and economic growth. It remains a puzzle whether private investment responds negatively or otherwise to higher public debt, which motivates this paper to examine the impacts of public debt on private investment in Malaysia. Debt-financing government spending on infrastructure and education can induce more private investments through strengthening physical and human capitals. However, if the government borrows from the domestic market, a high level of government debt may reduce the credit available and drive up the interest rate for private investment. Moreover, debt accumulation that is associated with uncertainties in fiscal stability and sustainability can inversely affect private investors' confidence - investors would expect lower potential earnings due to a higher tax rate for future public debt repayment.

Empirical results on debt-investment link remain inconclusive: some studies provided evidence that public debt spurs private investment while others find it crowds out private investment. Public debt can bring in more private investment if public debt is used to finance productive areas such as economic development (Lora, 2007) and public services and infrastructure support (Ang, 2009a). By contrast, many literatures also highlight that rising public debt may erode the net benefits of private investment in several ways: (i) it raises the cost of borrowing (i.e., interest rate) of the scarce domestic credit (Codogno, Favero, Missale, Portes, \& Thum, 2003; Huang, Pagano, \& Panizza, 2016), (ii) it increases the use of physical and financial resources that otherwise can be reserved for private investment (Ang, 2009a), (iii) it induces the expectation of higher future taxes (Bom, 2017), and (iv) it alters a country's debt portfolio and changes the demand for financial assets (da Silva, de Castro Pires, \& Bittes Terra, 2014).

Thus, this study attempts to fill this research gap by providing a developing country perspective on the relationship between public debt and private investment. Two questions are of the study's interest: (i) Does public debt crowd in or crowd out private investment in Malaysia?, and (ii) Does a link exist between them, and if there is an asymmetric relationship? This study employs non-linear autoregressive distributed lags (NARDL) estimation, which follows Shin, Yu and Greenwood-Nimmo's (2014) approach, to examine both long-run and short-run asymmetries in private investment in Malaysia from 1980 to 2016. It is important for this study to apply asymmetric modelling because 
imperfect capital markets and information could lead to interest rate discrimination in the credit market, whereby private and public sectors may pay different interest rates for acquiring capital.

The results show some evidence of private investment responding asymmetrically to changes in public debt in the long run and short run, though the effects of public debt reductions differ by time and definition of public debt. This study finds evidence of the presence of long-run asymmetry between private investment and total public debt, external debt and federal government debt. In the short run, by contrast, asymmetric relationship is present between private investment and domestic debt, external debt and federal government debt. The study also finds, in both the long run and short run, higher public debt crowding out private investment, which is in line with empirical studies in various countries that support the crowding-out effect hypothesis (Huang et al., 2016 in China; Huang, Panizza, \& Varghese, 2018 in advanced and emerging economies; King'wara, 2014 and Lidiema, 2018 in Kenya; Salotti \& Trecroci, 2012 in OECD countries; Shetta \& Kamaly, 2014 in Egypt). However, the effects of debt reductions differ between the long run and short run and by the measure of public debt. The study finds that public debt increases have larger effects on private investment in the long run but smaller effects in the short run than those of public debt reductions.

The paper proceeds as follows. Section 2 summarises the literatures relevant to public debt-private investment nexus. Section 3 describes the basic concepts of public debt-private investment link, the empirical strategy, data and variables. Section 4 discusses empirical results, and the last section concludes this study.

\section{Literature Review}

The theoretical literature on the relationship between private investment and public debt can be classified into four theoretical views. First, the classical view argues that government borrowing crowds out private investment through transferring resources (i.e., capital) from the private sector to relatively less productive public sector. In a market economy, government involvement is considered unnecessary because prices would adjust automatically to restore full-employment level of real income. Second, the neoclassical view further highlights that government borrowing from banks increases its purchasing power and allows it to bid away resources from other sectors. Under full employment conditions, government spending displaces private investment through driving up the price level and the interest rate for credits. Third, the Keynesian view, by contrast, argues that government spending can stimulate private investment through multiplier effects even though it recognises that fiscal stimulus could reduce private investment. If unemployment exists and the sensitivity of interest rate to investment is low, fiscal stimulus will have little or no impact on interest rate, which will increase total spending in public and private sectors (Friedman, 1978; Spencer \& Yohe, 1970). Fourth, the Ricardian view, which is based on Ricardian equivalence theorem, suggests no crowding-out effect because current interest rates and private investment will remain unchanged if people anticipate higher taxes in the future to repay public debt and savings will increase by the amount of the government debt issue to meet future tax liabilities (Barro, 1979; Bassanini \& Scarpetta, 2001; Gumus, 2003). 
Similarly, the empirical literature makes different conclusions on the crowding-out effect hypothesis. Several studies find the crowding-out effect of private investment by public debt. For example, Huang et al. (2016) found, using instrumental variables approach, that local public debt correlates negatively with the city-level investment ratio of domestic private manufacturing firms in China; the impact is greater for domestic firms that are more dependent on external funding. In cities with high government debt, firm-level investment is more sensitive to internal funding, probably due to external credit constraints. Huang et al. (2018) obtained similar findings in advanced and emerging economies. Using cointegration test and autoregressive distributed lag (ARDL) model, respectively, King'wara (2014) and Lidiema (2018) findings on Kenya is in line with the crowding-out effect hypothesis although the negative relationship diminishes in the long run. Salotti and Trecroci (2012) found, using a panel of 20 OECD countries, high public debt is associated with significant and linear declines of both aggregate investment spending and productivity growth. Shetta and Kamaly's (2014) vector autoregression analysis on Egypt also suggests government borrowing crowds out private investment. The crowding-out effect can take place through four channels: (i) 'liquidity constraints' hypothesis suggests that public borrowing induces higher interest rate for private investment by reducing available credits (Codogno et al., 2003; Hauner, 2009; Huang et al., 2016; Ismihan, \& Ozkan, 2012; Njuru, Ombuki, Wawire, \& Okeri, 2014; Shetta \& Kamaly, 2014); (ii) public investment competition takes away physical and financial resources that would otherwise be used for private investment (Ang, 2009a); (iii) debt-financed public investment can depress private investment through higher future tax rates, which will reduce returns to private investment (Bom, 2017); and (iv) heavy use of public debt may alter a country's debt portfolio and change the demand for financial assets in the country (da Silva et al., 2014).

On the other hand, some studies conclude otherwise that public debt crowds in private investment. For example, using vector error-correction model (VECM), Khan and Gill (2009) and Thilanka and Sri Ranjith (2018) found public debt spurs higher private investment in Sri Lanka and Pakistan, respectively. In the context of Pakistan, the authors argued that the positive effect is transferred through the provision of subsidy, transfer payments, and substantial amount of micro credits. Other papers suggest that the crowding-in effect of private investment occurs if public debt is used to finance economic development (Lora, 2007), public services and infrastructure support (Ang, 2009a) and capital (Şen \& Kaya, 2014).

Another strand of literature distinguishes the effects of domestic and external public debt and find debt-investment link varies by type of public debt, which support Friedman's (1978) theoretical argument - the government's choice of debt instrument determines the effects. Akomolafe, Bosede, Emmanuel and Mark (2015) found domestic debt crowds out domestic investment in both the short run and long run; however, external debt induces more domestic investment in the long run. Li and Mohan-Neil (2013), by contrast, found positive effects of domestic debt but no effects of external debt on domestic investment. Ebi and Imoke (2017) found a non-linear relationship between private investment and public debt: a moderate level of public debt spurs private investment while high level of public debt erodes the positive impact on investment. However, Checherita-Westphal and Rother (2012) found no impact of 
public debt on private investment for selected European countries although they found a non-linear relationship between per capita GDP growth and public debt. Similarly, Hajian, Mohamed and Habibullah (2017) concluded, using VECM, no evidence for crowding-out effect of public debt in Malaysia.

Most studies in Malaysia discuss other determinants of private investment with different views on crowding-out effects. For example, Ang (2010) and Choong, Law and Pek (2015), using ARDL and VECM respectively, found that government investment and foreign direct investment (FDI) crowd in private domestic investment. Other factors such as higher aggregate output, lower real user cost of capital and increased credit availability stimulate private investment while macroeconomic uncertainty discourages private investment. Tan and Tang (2012) corroborated the findings and suggested that there is bi-directional causality between the variables in the long run, and user cost of capital, public investment, and FDI show bi-directional causality with private investment and economic growth in the short run. Guimaraes and Unteroberdoerster (2006) suggested that real GDP is the key macroeconomic determinant that stimulates private investment in Malaysia while a shift in investors' perception and profitability, firm size, and financing constraints are firm-level factors that matter. Hassan, Othman and Karim (2011) found positive effects of public investment on private investment in industry and trade, transportation and communication, and construction using a panel co-integration analysis.

\section{Empirical Framework and Research Methodology}

Theoretically, private investment can be expressed as a flow of net receipts by a firm at time $t$, which is as follows:

$$
R(t)=p_{t} Q_{t}-w_{t} L_{t}-q_{t} I_{t}
$$

where $Q_{t}, L_{t}$ and $I_{t}$ represent level of output, labour input and net purchase of capital while $p_{t}, w_{t}$ and $q_{t}$ represent the corresponding prices. The integral of discounted net receipts shows the present value of a firm (Jorgenson, 1967), which the firm aims to maximise (Ang, 2009a, 2009b):

$$
\max W_{t}=\int_{0}^{\infty} e^{-\rho_{t}}\left(p_{t} Q_{t}-w_{t} L_{t}-q_{t} I_{t}\right) d_{t}
$$

where $\rho_{t}$ is the discounted rate of net receipts.

Jorgenson's $(1963,1967,1971)$ neoclassical model of investment postulates that a firm can obtain optimal capital accumulation by maximising its present value or profits at each point of time. Assuming certainty, equation (2) can be reduced to and expressed by a one-period static profit maximisation function (Ang, 2009a, 2009b; Nickell, 1978):

$$
\max \Pi_{t}=p_{t} Q_{t}-w_{t} L_{t}-r_{t} K_{t}
$$

where $r$ is the costs to acquire capital. Suppose the production function for the firm can be expressed by a simple Cobb-Douglas production function:

$$
Q_{t}=A K_{t}^{\alpha} L_{t}^{1-\alpha}
$$


Profit maximisation under the assumption of perfect competitive market requires:

$$
\begin{gathered}
\frac{\partial \Pi_{t}}{\partial K_{t}}=\alpha \frac{p_{t} A K_{t}^{\alpha} L_{t}^{1-\alpha}}{K_{t}}-r_{t}=0 \\
\alpha \frac{p_{t} A K_{t}^{\alpha} L_{t}^{1-\alpha}}{K_{t}}=r_{t} \Rightarrow r_{t}=\alpha \frac{Y_{t}}{K_{t}}
\end{gathered}
$$

where $\alpha$ is the coefficient of the nominal output $\left(Y_{t}\right)$ to capital $\left(K_{t}\right)$ ratio. The optimal level of capital is:

$$
K_{t}^{*}=\alpha \frac{Y_{t}}{r_{t}}
$$

Given that gross investment is the sum of net investment and replacement investment (Ang, 2009a, 2009b), the gross investment function is:

$$
I_{t}=\alpha \sum_{i=0}^{n} \beta_{i} \Delta\left(\frac{Y_{t-i}}{r_{t-i}}\right)+\delta K_{t-1}
$$

where net investment is the sum of the distributed lag on the past changes in desired capital stock, $\sum_{i=0}^{n} \beta_{i} \Delta K_{t-i}^{*}=\alpha \sum_{i=0}^{n} \beta_{i} \Delta\left(\frac{Y_{t-i}}{r_{t-i}}\right)$ and replacement investment is the capital stock by lagged one period that depreciated at a constant rate, $\delta K_{(t-1)}$ with $\delta$ as the depreciation rate of capital stock (Ang, 2009a, 2009b).

Suppose capital stock is only intermediated by $m$ banks in a competitive market and firms only finance their investment through borrowing from bank. At individual bank level, the amount of capital $\left(\kappa_{j, t}\right)$ that has been intermediated by a bank to the productive sector can be expressed as the fraction of current savings $\left(\varphi_{j, t} S_{j, t}\right)$ available for lending to firms:

$$
\kappa_{j, t}=\varphi_{j, t} S_{j, t}
$$

and

$$
K_{t}=\sum_{j}^{m} \kappa_{j, t}
$$

where $\kappa_{j}$ is the total quantity of resources being loaned by bank for investments and $S_{j}$ is current savings that has been deposited to bank $j ; \varphi_{j}$ represents the fraction of $S_{j}$ available and $0<\varphi_{i} \leq 1$. However, $\kappa_{j}$ is not only being available to businesses but also to public sector spending. Hence, equation (9) can also be expressed as:

$$
\kappa_{j, t}=\varphi_{j, t} S_{j, t}-\phi_{j, t} B_{t}
$$

and total capital stock available to private sector in the market can be written as follows:

$$
K_{t}=\sum_{j=1}^{m}\left(\varphi_{j, t} S_{j, t}-\phi_{j, t} B_{t}\right)
$$

where $B_{t}$ is government budget and $\phi_{j, t} B_{t}$ is the fraction of government budget that 
is financed by bank $j ; \phi_{j, t} B_{t}$ also represents the fraction of public debt that is held by bank-j. Denoting by $D_{j, t}=\phi_{j, t} B_{t}$ :

$$
\kappa_{j, t}=\varphi_{j, t} S_{j, t}-D_{j, t}
$$

and

$$
K_{t}=\sum_{j=1}^{m}\left(\varphi_{j, t} S_{j, t}-D_{j, t}\right) \Rightarrow K_{t}=\varphi_{t} S_{t}-D_{t}
$$

Equation (13) shows that public debt is a determinant of the availability of capital stock to private sector, as well as an elasticity parameter of the investment and present value maximisation condition of a firm. For these reasons, a simple linear specification is:

$$
I_{t}=f\left(Y_{t}, r_{t}, \varphi_{t} S_{t}, D_{t}\right)
$$

\section{Empirical Strategy}

This study employs non-linear autoregressive distributed lags (NARDL) estimation to account for possible divergence in cost of borrowing between private and public sectors under imperfect market and information in Malaysia. In general, the long-run model can be specified as follows:

$$
P I_{t}=a_{0}+a_{1} \text { Debt }_{t}+\sum_{j=2}^{n} a_{j} X_{j, t}+\varepsilon_{t}
$$

where $P I_{t}$ is private investment, Debt $t_{t}$ is the measurement of public debt in Malaysia, $X_{t}$ is a vector of control variables that includes private credit and interest rate, $a_{j}$ (where $j=$ $0,1, \ldots, n)$ are the long-run parameters, and $\varepsilon_{t}$ is the error term.

Equation (16) is then formulated as an asymmetric long-run equation:

$$
P I_{t}=a_{0}+a_{1}^{+} \text {Debt }_{t}^{+}+a_{1}^{-} \text {Debt }_{t}^{-}+\sum_{j=2}^{n} a_{j} X_{j, t}+\varepsilon_{t}
$$

$D e b t_{t}$ in equation (17) is decomposed into $D e b t_{t}^{+}$and $D e b t_{t}^{-}$to show partial sum of positive and negative changes in Debt $_{t}$ :

$$
\operatorname{Debt}_{t}^{+}=\sum_{i=1}^{t} \Delta D e b t_{i}^{+}=\sum_{i=1}^{t} \max \left(\Delta D e b t_{j}, 0\right)
$$

and

$$
D_{e b t_{t}^{-}}=\sum_{i=1}^{t} \Delta D e b t_{i}^{-}=\sum_{i=1}^{t} \min \left(\Delta D e b t_{j}, 0\right)
$$

Based on equation (17), $a_{1}^{+}$captures the long-run relationship between private investment and higher public debt while $a_{1}^{-}$. the long-run relationship between private investment and public debt reduction. A positive $a_{1}^{+}$indicates crowding-in effects of public debt; otherwise, it shows higher public debt crowding out private investment. $a_{1}^{+}$ and $a_{1}^{-}$.are compared to identify whether a rise in public debt and a drop in public debt have a same degree of long-run effect on private investment. This study posits that the degree of the impact differs between public debt increases and public debt reduction: an increase in public debt leads to relatively higher long-run changes in private 
investment, i.e., $a_{1}^{+}>a_{1}^{-}$, which reflects asymmetric long-run relationship between the two variables. If a long-run relationship is identified, both long-run and short-run asymmetries will be examined, which can be specified in the following error correction form:

$$
\begin{aligned}
& \Delta P I_{t}=\alpha_{0}+\gamma_{1} P I_{t-1}+a_{1}^{+} D e b t_{t}^{+}+a_{1}^{-} D e b t_{t}^{-}+\sum_{j=2}^{n} \alpha_{j} X_{j, t}+ \\
& \sum_{i=0}^{t}\left(\beta_{1, i}^{+} \Delta D e b t_{t-i}^{+}+\beta_{1, i}^{-} \Delta D e b t_{t-i}^{-}\right)+\sum_{j=2}^{n} \sum_{i=0}^{t} \beta_{j, i} \Delta X_{j, t-i}+\varepsilon_{t}
\end{aligned}
$$

where all variables are as defined above, $n$ and $t$ are lag orders and the long-run coefficients are $a_{1}^{+}=-\alpha_{1}^{+} / \gamma_{1}$ and $a_{1}^{-}=-\alpha_{1}^{-} / \gamma_{1}$, which measure long-run impacts of public debt increases and public debt reduction on private investment, respectively; the null hypothesis for long-run asymmetry is $a_{1}^{+}=a_{1}^{-}$. The short-run coefficients, $\beta_{i}^{+}$and $\beta_{i}^{-}$, measure the short-run effects of public debt increases and public debt reduction, respectively, on private investment; for the short-run asymmetry, the null hypothesis is $\sum_{i=0}^{t} \beta_{1, i}^{+}=\sum_{i=0}^{t} \beta_{1, i}^{-}$.

Empirical estimation of equation (20), the NARDL model, involves several steps. First, this study conducts unit root tests - ADF and PP unit root tests - to check whether I(2) variables are present to ensure the computed F-statistics for testing cointegration is valid. Second, using the standard OLS estimation method, the study uses the generalto-specific approach to trim insignificant lags in the equation. Third, this study uses the Wald F test, which is based on Pesaran, Shin and Smith's (2001) approach, to test for the presence of cointegration among the variables in the trimmed NARDL model; the null hypothesis is $\gamma_{1}=\alpha_{1}^{+}=\alpha_{1}^{-}=\alpha_{j}=0$. Fourth, with the variables cointegrated, the study examines the long-run and short-run asymmetries in the relationship between private investment and public debt.

\subsection{Data and Variables}

This study employs time series data that covers the sample period of 1980 to 2016 or 37 observations. Private investment, the dependent variable, is the purchase of capital assets that includes land, buildings, machineries and equipment that are expected to produce income, to appreciate in value, or both. These assets are usually not easily sold and are purchased for generating profits to investors. The variable is measured as a share of GDP (percentage of GDP). Public debt, the variable of interest, is the total debt of the federal government. This study uses four measures of public debt: total public debt as a share of GDP, total external debt as a share of GDP, total domestic debt as a share of GDP and federal government debt as a share of GDP; all variables are in percentage.

Equations (16), (17), (20) and (21) include two control variables, namely, domestic credit to private sector and interest rate. Domestic credit to private sector, which includes loans, purchases of non-equity securities, and trade credits and other account receivable, is measured as a share of GDP. Interest rate is measured by the base lending 
Table 1. Descriptive statistics

\begin{tabular}{lrrrrr}
\hline Variable & N & Mean & SD & Min. & Max. \\
\hline Private investment/GDP & 37 & 30.695 & 8.322 & 18.930 & 46.920 \\
Total government debt/GDP & 37 & 42.612 & 13.258 & 17.530 & 69.340 \\
Total domestic debt/GDP & 37 & 29.607 & 13.418 & 12.600 & 57.280 \\
Total external debt/GDP & 37 & 13.005 & 4.026 & 4.930 & 22.610 \\
Federal government debt/GDP & 37 & 5.528 & 3.761 & 1.660 & 14.770 \\
Interest rate & 37 & 7.713 & 1.644 & 5.620 & 11.540 \\
Domestic credit to private sector/GDP & 37 & 106.275 & 26.464 & 49.910 & 158.500 \\
\hline
\end{tabular}

Note: All variables are measured in percentage.

rate charged on the short- and medium-term financing needs of the private sector. The data for all variables are collected and compiled from Bank Negara Malaysia (BNM), Department of Statistics Malaysia (DoS) and Economic Planning Unit of Malaysia (EPU).

Table 1 presents the descriptive statistics. The mean in the first row shows that, on average, total private investment as a share of GDP is $30.695 \%$ over the past four decades, with the variation of $8.322 \%$. In the second row, the mean shows that the average public debt is $42.612 \%$ of the GDP; the highest value is $69.34 \%$ while the lowest value is $17.53 \%$, with the variation of $13.258 \%$. The statistics in the table also show that domestic debt accounts for the largest share of Malaysia's total public debt, total external debt the second, and federal government debt the least. The variation in domestic debt is also much higher compared to total external debt and federal government debt. As for interest rate, the statistics show that interest rate remains stable with small variation. Of all the variables, domestic credit to private sector has the highest mean value, which is $106.275 \%$, and has the greatest variation of $26.464 \%$.

\section{Empirical Analysis}

The analysis starts with conducting the augmented Dickey-Fuller (ADF) and PhillipsPerron (PP) unit root tests that include both constant and trend term to ensure no I(2) variables are present in the NARDL estimation, which is required in the bounds testing procedure.

Table 2, which presents the results of the unit root tests, shows domestic credit to private sector, interest rate and total external debt are I(0); while private investment, total public debt, total domestic debt and federal government debt are I(1). None of these variables is I(2). The tests conclude that all variables are stationary and integrated of order 1; both the ADF and PP unit root tests suggest the same conclusion.

As a step before the bounds testing procedure, this study uses the general-tospecific approach to trim down insignificant lags in equation (20) by using the standard OLS estimation method. The maximum lag order considered is two. Table 3 reports the bounds Wald $\mathrm{F}$ test statistics and diagnostic test results. The upper panel of Table 3 shows that there is cointegration for all four measures of public debt - that is, they comove in the long run. The results of the diagnostic tests suggest that the model has no autocorrelation and no heteroscedasticity and it meets the normality assumption. 
Table 2. ADF and PP unit root tests

\begin{tabular}{|c|c|c|c|c|c|c|c|}
\hline & $\begin{array}{c}\text { Private } \\
\text { investment }\end{array}$ & $\begin{array}{c}\text { Domestic } \\
\text { credit to } \\
\text { private sector }\end{array}$ & $\begin{array}{l}\text { Interest } \\
\text { rate }\end{array}$ & $\begin{array}{l}\text { Total } \\
\text { public } \\
\text { debt }\end{array}$ & $\begin{array}{l}\text { Total } \\
\text { domestic } \\
\text { debt }\end{array}$ & $\begin{array}{c}\text { Total } \\
\text { external } \\
\text { debt }\end{array}$ & $\begin{array}{c}\text { Federal } \\
\text { government } \\
\text { debt }\end{array}$ \\
\hline \multicolumn{8}{|c|}{ Augmented Dickey-Fuller test } \\
\hline $\mathrm{I}(0)$ & -1.439 & $-2.817^{*}$ & $-3.042 * *$ & -1.740 & -0.752 & $-3.307^{* *}$ & -1.304 \\
\hline $\mathrm{I}(1)$ & $-4.780 * * *$ & $-5.388 * * *$ & $-4.262 * * *$ & $-3.181 * *$ & $-3.714 * * *$ & $-4.581 * * *$ & $-3.765 * * *$ \\
\hline \multicolumn{8}{|c|}{ Phillips-Perron test } \\
\hline $\mathrm{I}(0)$ & -1.586 & $-2.800 *$ & $-3.058 * *$ & -2.260 & -1.030 & $-3.369 * *$ & -1.235 \\
\hline $\mathrm{I}(1)$ & $-4.800 * * *$ & $-5.380 * * *$ & $-6.328 * * *$ & $-3.060 * *$ & $-3.726 * * *$ & $-4.532 * * *$ & $-3.705 * * *$ \\
\hline
\end{tabular}

Note: $* * *$, and $* * *$ denote significance at $10 \%, 5 \%$, and $1 \%$ respectively.

Table 3. Bound tests and diagnostic tests

\begin{tabular}{lcccc}
\hline & $\begin{array}{c}\text { Total } \\
\text { public debt } \\
(1)\end{array}$ & $\begin{array}{c}\text { Public debt by } \\
\text { domestic creditor } \\
(2)\end{array}$ & $\begin{array}{c}\text { Public debt by } \\
\text { foreign creditor } \\
(3)\end{array}$ & $\begin{array}{c}\text { Federal } \\
\text { public debt } \\
(4)\end{array}$ \\
\hline $\begin{array}{l}\text { Bounds Test } \\
W_{\text {test }}\end{array}$ & $7.357^{* * *}$ & $7.522^{* * *}$ & $4.540^{*}$ & $9.165^{* * *}$ \\
Diagnostic Tests & & & & \\
$\chi^{2}$ SC & 0.292 & 2.483 & 0.575 & 1.205 \\
$\chi^{2}$ HET & 10.515 & 7.539 & 6.673 & 11.711 \\
$\chi^{2}$ NOR & 0.669 & 0.372 & 1.449 & 1.601 \\
\hline
\end{tabular}

Notes: $*, * *$, and $* * *$ denote significance at $10 \%, 5 \%$, and $1 \%$ respectively. $\mathrm{W}_{\text {test }}$ indicates Wald test for cointegration, and the critical values are obtained from Narayan (2005). Case III for $k=4, n=37$ : $1 \%(4.428,6.250), 5 \%(3.202,4.544)$, and $10 \%(2.660,3.838) . \chi^{2} S C, \chi^{2} H E T$, and $\chi^{2}$ NOR denote serial correlation, heteroscedasticity, and normality of error terms.

Table 4 presents the NARDL results: the bottom of the table reports the long-run coefficients in equation (17) and long-run asymmetry and short-run asymmetry tests; the upper panel reports the short-run coefficients in equation (20). The Wald $F$ test statistic $\left(\mathrm{W}_{\mathrm{LR}}\right)$ for the null hypothesis of long-run symmetries (i.e., $\left.a_{1}^{+}=a_{1}^{-}\right)$is statistically significant in all cases (columns (1), (3) and (4)) except total domestic debt, which suggests that, in the long run, private investment responds asymmetrically to changes in total debt, total external debt and federal government debt. The short-run asymmetry test also rejects the null hypothesis of short-run symmetry (i.e., $\sum_{i=0}^{t} \beta_{1, i}^{+} \Rightarrow \sum_{i=0}^{t} \beta_{1, i}^{-}$) for all debt variables (columns (2)-(3)) except total public debt. In sum, the results show some evidence of asymmetric relationship between private investment and public debt in the long run and the short run.

The long-run estimates for public debt ( $D e b t_{t-i}^{+}$and $\left.D e b t_{t-i}^{-}\right)$in columns (1)-(2) show that a percentage point increase in total public debt and domestic debt, respectively, is associated with 0.242 and 0.072 percentage point lower private investment, while 
Table 4. NARDL estimation results

\begin{tabular}{|c|c|c|c|c|}
\hline & $\begin{array}{c}\text { Total } \\
\text { public debt } \\
\text { (1) }\end{array}$ & $\begin{array}{c}\text { Total } \\
\text { domestic debt } \\
\text { (2) }\end{array}$ & $\begin{array}{c}\text { Total } \\
\text { external debt } \\
\text { (3) }\end{array}$ & $\begin{array}{l}\text { Federal } \\
\text { government debt } \\
\text { (4) }\end{array}$ \\
\hline $\mathrm{PI}_{\mathrm{t}-1}$ & $-0.331 * * *$ & $-0.462 * * *$ & $-0.246 * *$ & $-0.241 * *$ \\
\hline Debt $_{t-1}^{+}$ & -0.080 & -0.033 & $-0.271 * *$ & $-0.372 * * *$ \\
\hline Debt $_{t-1}^{-}$ & $0.336 * *$ & 0.112 & -0.116 & $-0.090 * *$ \\
\hline $\mathrm{PC}_{\mathrm{t}-1}$ & 0.152 & -0.442 & -0.016 & -0.060 \\
\hline $\begin{array}{l}\mathrm{BLR}_{\mathrm{t}-1} \\
\Delta \mathrm{PI}\end{array}$ & $-0.062 * * *$ & -0.009 & $-0.035 * *$ & $-0.075^{* * *}$ \\
\hline $\begin{array}{l}\Delta \mathrm{PI}_{\mathrm{t}-1} \\
\Delta \mathrm{PI}_{\mathrm{t}-2} \\
\Delta \mathrm{PI}_{\mathrm{t}-3} \\
\Delta \mathrm{PI}_{\mathrm{t}-4}\end{array}$ & & & & \\
\hline $\begin{array}{l}\Delta \text { Debt }^{+} \\
\Delta \text { Debt }_{\mathrm{t}-1}^{+}\end{array}$ & $-0.914 * * *$ & $-0.899 * * *$ & $-0.537 * * *$ & $-0.533 * * *$ \\
\hline $\begin{array}{l}\Delta \text { Debt }_{\mathrm{t}-2}^{+} \\
\Delta \mathrm{Debt}_{\mathrm{t}-3}^{+} \\
\Delta \mathrm{Debt}_{\mathrm{t}-4}^{+}\end{array}$ & & & & $-0.341 * *$ \\
\hline$\Delta$ Debt $^{-}$ & $1.379 *$ & $-2.254 * * *$ & & \\
\hline$\Delta$ Debt $_{\mathrm{t}-1}^{-}$ & $-2.276 * * *$ & & 0.365 & \\
\hline $\begin{array}{l}\Delta \mathrm{Debt}_{\mathrm{t}-2}^{-} \\
\Delta \mathrm{Debt}_{\mathrm{t}-3}^{-} \\
\Delta \mathrm{Debt}_{\mathrm{t}-4}^{-}\end{array}$ & & & & $0.692 * * *$ \\
\hline $\begin{array}{l}\Delta \mathrm{PC} \\
\Delta \mathrm{PC}_{\mathrm{t}-1}\end{array}$ & $0.534 * *$ & & & \\
\hline $\begin{array}{l}\Delta P C_{t-2} \\
\Delta P C_{t-3} \\
\Delta P C_{t-4}\end{array}$ & $0.354^{* *}$ & 0.182 & & $0.296 * *$ \\
\hline$\triangle \mathrm{BLR}$ & & $0.035^{*}$ & & \\
\hline $\begin{array}{l}\Delta \mathrm{BLR}_{\mathrm{t}-1} \\
\Delta \mathrm{BLR}_{\mathrm{t}-2} \\
\Delta \mathrm{BLR} \mathrm{R}_{\mathrm{t}-3} \\
\Delta \mathrm{BLR} \mathrm{R}_{\mathrm{t}-4}\end{array}$ & & $-0.029 *$ & & \\
\hline Constant & $1.148^{*}$ & $1.904 * * *$ & $1.646^{* * *}$ & $2.373 * * *$ \\
\hline \multicolumn{5}{|c|}{ Long-Run Asymmetries } \\
\hline Debt $_{t-1}^{+}$ & -0.242 & -0.072 & $-1.100 * * *$ & $-1.546 * * *$ \\
\hline Debt $_{\mathrm{t}-1}^{-}$ & 1.015 & 0.243 & $-0.472 *$ & $-0.378 * *$ \\
\hline$W_{L R}$ & $5.379 * *$ & 1.204 & $9.800 * * *$ & $11.587^{* * *}$ \\
\hline \multicolumn{5}{|c|}{ Short-Run Asymmetries } \\
\hline $\mathrm{W}_{\mathrm{SR}}$ & 0.001 & $3.527^{*}$ & $6.313^{* *}$ & $27.155^{* * *}$ \\
\hline
\end{tabular}

Notes: $\mathrm{W}_{\mathrm{LR}}$ and $\mathrm{W}_{\mathrm{SR}}$ indicate $\mathrm{Wald} \mathrm{F}$ test for long-run asymmetry and short-run asymmetry respectively. $*, * *$, and $* * *$ denote significance at $10 \%, 5 \%$, and $1 \%$ respectively. 
reductions in the two types of debt are associated with lower private investment, but the estimates are statistically insignificant. In columns (3) and (4), the long-run estimates suggest that one percentage point increase in external debt and federal government debt, respectively, crowds out private investment by 1.1 and 1.546 percentage points; the estimates are statistically significant at $1 \%$ level. However, reductions in external debt and federal government debt, respectively, induce 0.472 and 0.378 percentage point higher private investment, and the estimates are statistically significant. Overall, public debt increases have a stronger asymmetric longrun relationship with private investment. The results on larger effects of public debt increases may suggest that rising public debt retards private investments because investors perceive greater economic uncertainty and limited government financial discipline which is harmful to the business environment. By contrast, when economic uncertainty decreases, investment activities may not necessarily rebound immediately (Foerster, 2014). Continuous debt accumulation, therefore, may trigger conservative investment decisions that stifle output growth in the long term, which explains the crowding-out effect of public debt (Chudik, Mohaddes, Pesaran, \& Raissi, 2018).

As for the short-run estimation, the upper panel of Table 4 shows some evidence that private investment responds asymmetrically to changes in public debt. Column (1) shows that both total public debt increases and reductions lead to 0.914 and 1.379 percentage point lower private investment respectively; the estimates are statistically significant and larger for total public debt reductions. By contrast, the estimates in column (2) show that higher domestic debt discourages private investment: one percentage point increase in domestic debt reduces private investment by 0.899 percentage point. Meanwhile, lower domestic debt induces 2.254 percentage point higher private investment; the effect is larger than domestic debt increases. However, in column (3), while the estimate of external debt increases suggests a crowding-out effect, the estimate of external debt reductions suggests no evidence that private investment responds to external debt reductions. In column (4), the estimates for both federal government debt increases and reductions are statistically significant, which show evidence of short-run asymmetric relationship between private investment and federal government debt. Private investment decreases by 0.341 and 0.692 percentage point, respectively, in response to a percentage change in federal government debt; the effect is larger for federal government debt reductions. In sum, public debt reductions have a larger effect in the short-run although there is no evidence that external debt reductions matter.

To sum up, the findings on the presence of asymmetry in the relationship between private investment and public debt are in line with the literature that studies non-linear relationship between the two variables (see, e.g., Ebi \& Imoke, 2017). Both long-run and short-run results suggest that higher public debt crowds out private investment, which is in line with the crowding-out effect hypothesis and empirical studies in China (Huang et al., 2016), advanced and emerging economies (Huang et al., 2018), Kenya (King'wara, 2014; Lidiema, 2018), OECD countries (Salotti \& Trecroci, 2012), and Egypt (Shetta \& Kamaly, 2014). Higher public debt may increase cost of borrowing for private investment through two ways. One, higher demand for funds by the public sector could reduce availability of funds, which increases interest rate. Two, possible 
risk of government solvency could also cause higher cost of borrowing if creditors impose higher interest rate for higher risk (Hauner, 2009). The results on public debt reductions show the effects of lower public debt on private investment differ between the long run and short run and differ by the measures of public debt, which are in line with Friedman's (1978) theoretical argument that the government's choice of debt instrument determines the effects of public debt. The change in debt-investment link is also in line with several studies in the literature (see, e.g., Akomolafe, Bosede, Emmanuel, \& Mark, 2015; Li \& Mohan-Neil, 2013).

\section{Conclusion}

One of the questions on the rising public debt is whether private investment responds negatively or otherwise to higher public debt. It remains a puzzle and motivates this study to examine the impacts of public debt on private investment in Malaysia. Specifically, this paper intends to examine the existence of asymmetric effect of public debt on private investment in Malaysia. As Malaysia's public debt is rising in recent years, it raises concerns on the country's debt profile and sovereignty. Continuous debtfinanced government spending, which is usually associated with fiscal uncertainties, can inversely affect private investors' confidence - that is, they would expect lower future earnings due to a higher tax rate for future public debt repayment.

Using the NARDL estimation, this study finds some evidence of asymmetric response of private investment to changes of public debt in both the long and short run. This study also observes evidence of long-run asymmetry between private investment and total public debt, external debt and federal government debt. In the short run, asymmetric relationship is present between private investment and domestic debt, external debt and federal government debt. The results also conclude that, in both the long run and short run, higher public debt crowds out private investment. These findings are in line with the crowding-out effect hypothesis presented in Huang et al. (2016), Huang et al. (2018) and so forth. Public debt increases have larger effects on private investment in the long run but smaller effects in the short run than those of public debt reductions.

The findings on asymmetric public debt-investment link and crowding-out effects may have important policy implications. The long-run asymmetries show that public debt increases have a greater crowding-out effect than the positive effect of public debt reductions, which suggest that rising public debt can be detrimental to private investment growth in the long term. Therefore, cutting public debt and stricter financial discipline could be a better way out for the government to stimulate economic growth, in which private investment is one of the key stimuli. Cutting government spending is one way to reduce debt and it is less harmful to the economy than raising taxes (Alesina, Favero, \& Giavazzi, 2018). Moreover, the government always needs fiscal discipline because government spending may sometimes fail to stimulate economic activity and growth (Alesina \& Perotti, 1996; Riedl, 2008).

Although the study has contributed a piece to the puzzle on asymmetric relationship between private investment and public debt, limitations remain. Since the government is unlikely to maintain zero debt at any point of time, knowing the optimal level 
of public debt or the threshold of public debt is therefore important, of which future research can focus on.

\section{References}

Alesina, A., Favero, C.A., \& Giavazzi, F. (2018). Climbing out of debt. Finance \& Development, 55(1), 6-11.

Alesina, A, \& Perotti, R. (1996). Fiscal discipline and the budget process. The American Economic Review, 86(2), 401-407.

Ang, J.B. (2009a). Private investment and financial sector policies in India and Malaysia. World Development, 37(7), 1261-1273. https://doi.org/10.1016/j.worlddev.2008.12.003

Ang, J.B. (2009b). The determinant of private investment. In Ang, J.B. (Ed.), Financial development and economic growth in Malaysia (pp. 118-130). New York, NY: Routledge.

Ang, J.B. (2010). Determinants of private investment in Malaysia: What causes the postcrisis slumps? Contemporary Economic Policy, 28(3), 378-391. https://doi.org/10.1111/j.14657287.2009.00155.x

Akomolafe, K.J., Bosede, O., Emmanuel, O., \& Mark. A. (2015). Public debt and private investment in Nigeria. American Journal of Economics, 5(5), 501-507.

Barro, R.J. (1979). On the determination of the public debt. Journal of Political Economy, 87(5), 940-971. https://doi.org/10.1086/260807

Bassanini, A., \& Scarpetta, S. (2001). Does human capital matter for growth in OECD countries?: Evidence from pooled mean-group estimates (OECD Economics Department Working Papers, 282). Paris: OECD Publishing. Retrieved from https://ideas.repec.org/p/oec/ecoaaa/282-en. html

Bom, P.R.D. (2017). Factor-biased public capital and private capital crowding out. Journal of Macroeconomics, 52(June), 100-117. https://doi.org/10.1016/j.jmacro.2017.03.002

Checherita-Westphal, C., \& Rother, P. (2012). The impact of high sovereign debt on economic growth and its channels: An empirical investigation for the euro area. European Economic Review, 56(7), 1392-1405. https://doi.org/10.1016/j.euroecorev.2012.06.007

Choong, C.K., Law, S.H., \& Pek, C.K. (2015). The linkages between private and public investments in Malaysia: The role of foreign direct investment. International Journal of Economics and Management, 9(1), 139-153.

Chudik, A., Mohaddes, K., Pesaran, M.H., \& Raissi, M. (2018). Rising public debt to GDP can harm economic growth. Economic Letter, 13(3), 1-4.

Codogno, L., Favero, C., Missale, A., Portes, R., \& Thum, M. (2003). Yield spreads on EMU government bonds. Economic Policy, 18(37), 503-532.

da Silva, C.G., de Castro Pires, M.C., \& Bittes Terra, F.H. (2014). The effects of public debt management on macroeconomic equilibrium: An analysis of the Brazilian economy. Economia, 15(2), 174-188. https://doi.org/10.1016/j.econ.2014.06.002

Ebi, B.O., \& Imoke, I.D. (2017). Public debt carrying capacity and debt transmission channels: The Nigerian experience. International Journal of Economics and Financial Issues, 7(5), 41-52.

Edge Weekly. (2018, January 6). Malaysia's spiralling debt burden. Edge Weekly: The Edge Markets. Retrieved from http://www.theedgemarkets.com/article/malaysias-spiralling-debtburden

Friedman, B.M. (1978). Crowding out or crowding in? The economic consequences of financing government deficits. Brookings Papers on Economic Activity, 1978(3), 593-641.

Foerster, A.T. (2014). The asymmetric effects of uncertainty. Economic Review, Issue Q III, 5-26.

Guimaraes, R., \& Unteroberdoerster, O. (2006). What's driving private investment in Malaysia? Aggregate trends and firm-level evidence (IMF Working Paper No. 06/190). Washington, 
DC: International Monetary Fund. Retrieved from https://www.imf.org/en/Publications/WP/ Issues/2016/12/31/Whats-Driving-Private-Investment-in-Malaysia-Aggregate-Trends-andFirm-Level-Evidence-19467

Gumus, E. (2003). Crowding-out hypothesis versus Ricardian equivalence proposition: Evidence from literature (MPRA Working Paper No. 42141). Munich: Munich Personal RePEc Archive. Retrieved from https://mpra.ub.uni-muenchen.de/42141/

Hajian, H., Mohamed, A., \& Habibullah, M.S. (2017). The impact of government debt on output, private investment and human capital stock in Malaysia. Global Conference on Business and Economics Research (GCBER 2017), 14-15 August. Universiti Putra Malaysia, Serdang. Retrieved from http://www.econ.upm.edu.my/kandungan/the_impact_of_government_ debt_on_output_private_investment_and_human_capital_stock_in_malaysia-33205

Hassan, S., Othman, Z., \& Karim, M.Z.A. (2011). Private and public investment in Malaysia: A panel time-series analysis. International Journal of Economics and Financial Issues, 1(4), 199-210.

Haswidi, A. (2018, July 16). Southeast Asia's foreign debt spirals: High levels of borrowing a concern for six nations in region. Nikkei Asian Review (FT Confidential Research). Retrieved from https://asia.nikkei.com/Editor-s-Picks/FT-Confidential-Research/Southeast-Asia-sforeign-debt-spirals

Hauner, D. (2009). Public debt and financial development. Journal of Development Economics, 88(1), 171-183. https://doi.org/10.1016/j.jdeveco.2008.02.004

Huang, Y., Pagano, M., \& Panizza, U. (2016). Public debt and private firm funding: Evidence from Chinese cities (IHEID Working Papers 10-2016, Economics Section), Geneva: The Graduate Institute of International Studies. Retrieved from https://ideas.repec.org/p/gii/giihei/ heidwp10-2016.html

Huang, Y., Panizza, U., \& Varghese, R. (2018). Does public debt crowd out corporate investment? International evidence (IHEID Working Papers 08-2018, Economics Section). Geneva: The Graduate Institute of International Studies. Retrieved from https://ideas.repec.org/p/gii/ giihei/heidwp08-2018.html

Ismihan, M., \& Ozkan, F.G. (2012). Public debt and financial development: A theoretical exploration. Economics Letters, 115(3), 348-351. https://doi.org/10.1016/j.econlet.2 011.12.040

Jorgenson, D.W. (1963). Capital theory and investment behavior. The American Economic Review, 53(2), 247-259.

Jorgenson, D.W. (1967). The theory of investment behavior. In R. Ferber (Ed.), Determinants of investment behavior (pp. 129-175). New York, NY: National Bureau of Economic Research.

Jorgenson, D.W. (1971). Econometric studies of investment behavior: A survey. Journal of Economic Literature, 9(4), 1111-1147.

Khan, R.E.A., \& Gill, A.R. (2009). Crowding out effect of public borrowing: A case of Pakistan (MPRA Paper No. 16292). Munich: Munich Personal RePEc Archive. Retrieved from https:// mpra.ub.uni-muenchen.de/16292/

King'wara, R. (2014). The impact of domestic public debt on private investment in Kenya. Developing Country Studies, 4(22), 88-96.

Li, M., \& Mohan-Neil, S. (2013). Does external debt increase net private wealth? The relative impact of domestic versus external debt on the US demand for money. Journal of Applied Finance and Banking, 3(5), 85-91.

Lidiema, C. (2018). Effects of government borrowing on private investment in Kenya. Journal of Finance and Economics, 6(2), 49-59. https://doi.org/10.12691/jfe-6-2-3

Lora, E.A. (2007). Public investment in infrastructure in Latin America: Is debt the culprit? (InterAmerican Development Bank Working Paper No. 595). Washington, DC: Inter-American Development Bank. Retrieved from https://publications.iadb.org/publications/english/ document/Public-Investment-in-Infrastructure-in-Latin-America-Is-Debt-the-Culprit.pdf 
Narayan, P.K. (2005). The saving and investment nexus for China: Evidence from cointegration test. Applied Economics, 37(17), 1979-1990. https://doi.org/10.1080/00036840500278103

Nickell, S.J. (1978). The investment decisions of firms. Cambridge: Cambridge University Press.

Njuru, S.G., Ombuki, C., Wawire, N., \& Okeri, S. (2014). Impact of government expenditure on private investments in Kenya. Journal of Economics, 2(8), 1-19.

Pesaran, M.H, Shin, Y., \& Smith, R.J. (2001). Bounds testing approach to the analysis of level relationship. Journal of Applied Econometrics, 16(3), 289-326. https://doi.org/10.1002/jae.616

Riedl, B.M. (2008). Why government spending does not stimulate economic growth (The Heritage Foundation Backgrounder, November, no. 2208). Washington, DC: The Heritage Foundation. Retrieved from https://www.heritage.org/budget-and-spending/report/why-governmentspending-does-not-stimulate-economic-growth

Salotti, S., \& Trecroci, C. (2012). Even worse than you thought: The impact of government debt on aggregate investment and productivity. Unpublished paper. Retrieved from https://ecomod. net/system/files/saltreFinal.pdf

Şen, H., \& Kaya, A. (2014). Crowding-out or crowding-in? Analyzing the effects of government spending on private investment in Turkey. Panoeconomicus, 61(6), 631-651. https://doi. org/10.2298/PAN1406631S

Shetta, S., \& Kamaly, A. (2014). Does the budget deficit crowd-out private credit from the banking sector? The case of Egypt. Topics in Middle Eastern and African Economies, 16(2), 251-279.

Shin, Y., Yu, B., \& Greenwood-Nimmo, M. (2014). Modelling asymmetric cointegration and dynamic multipliers in a nonlinear ARDL framework. In R. Sickles \& W. Horrace (Eds.), Festschrift in Honor of Peter Schmidt (pp. 281-314). New York, NY: Springer.

Spencer, R.W., \& Yohe, W.P. (1970). The "crowding out" of private expenditures by fiscal policy actions (Federal Reserve Bank of St. Louis, October Issue, pp. 12-24). St. Louis, MO: Federal Reserve Bank of St. Louis. Retrieved from https://pdfs.semanticscholar.org/e95d/ d5ecc5a376bb6b06816fc46ee67d4786d922.pdf

Tan, B.W., \& Tang, C.F. (2012). The dynamic relationship between private domestic investment, the user cost of capital, public investment, foreign direct investment and economic growth in Malaysia. Economia Politica, 2, 221-246. Retrieved from https://ideas.repec.org/a/mul/ jb33yl/doi10.1428-37630y2012i2p221-246.html

Thilanka, H.R.A.C., \& Sri Ranjith, J.G. (2018). The impact of public debt on private investment: Sri Lanka experience. International Journal of Business and Social Research, 8(8), 1-10. 